\title{
LECTURE
}

\section{EXIT, VOICE, AND DISLOYALTY}

\author{
HEATHER K. GERKEN†
}

INTRODUCTION

This Lecture begins with a puzzle about Albert Hirschman's famous work, Exit, Voice, and Loyalty: ${ }^{1}$ Why do we make much of exit and voice but utterly neglect loyalty? It's a question that goes well beyond Hirschman's book. For example, much of constitutional theory is preoccupied with a single question: What does a democracy owe its minorities? And most of the answers to this question fit naturally into the two categories Hirschman made famous: voice and exit. On both the rights side and the structural side of constitutional theory, scholars worry about providing minorities with an adequate level of influence. And the solutions they propose almost inevitably offer minorities a chance at voice or exit, as if no other option exists. The First Amendment, for instance, offers minorities the right to free speech (voice) and private association (exit). Similarly, structural arrangements give minorities the chance to vote in national elections (voice) and in state elections (exit).

The Brainerd Currie Memorial Lecture has been held annually at Duke University School of Law since 1967. It is both an honor and a tradition for the Duke Law Journal to publish the remarks of the distinguished speakers whom our faculty members invite to deliver each year's lecture. Heather K. Gerken delivered this Lecture at Duke Law School on March 27, 2012.

Copyright $(2013$ by Heather K. Gerken.

$\dagger$ J. Skelly Wright Professor of Law, Yale Law School. I am deeply grateful to the Duke Law faculty for inviting me to deliver this paper as the Brainerd Currie Memorial Lecture and for providing such helpful feedback. For excellent comments and suggestions, I owe thanks to Bruce Ackerman, Yair Listokin, Luke Norris, Tom Wolf, Ernie Young, and the faculties of Cardozo Law School, George Washington University Law School, Quinnipiac University Law School, Tel Aviv University Law School, University of Iowa Law School, University of North Carolina Law School, and University of Pennsylvania Law School. Excellent research assistance on this paper and the larger book project undergirding it was provided by Rob Cobbs, Melissa Collins, Alex Hemmer, Erin Miller, Luke Norris, Daniel Schuker, Matt Smith, Elizabeth Wilkins, and Tom Wolf.

1. Albert O. Hirschman, Exit, Voice, AND Loyalty: Responses to Decline in FIRMS, ORGANIZATIONS, AND STATES (1970). 
Exit and voice are not, however, the only options available to a minority group seeking influence. That's because much of the nation's administrative structure looks more like Tocqueville's democracy than Weber's bureaucracy. In our highly decentralized and partially politicized system, minorities can wield influence over national policy because they routinely administer it. ${ }^{2}$ State officials regularly run federal programs, often with governors and state legislators serving nominally bureaucratic roles. Federal policy is often implemented by local juries and local prosecutors, state and local school boards, and state-created agencies. Because national minorities often constitute local majorities in the United States, these institutional arrangements ensure that those with outlier views help set federal policy.

As policymaking insiders, minorities can resist federal policy from within rather than challenge it from without. A jury can nullify a law it dislikes. A state agency may be hostile to the federal law it is implementing. A school board can find ways to introduce religion into the classroom. Bureaucrats may administer an entitlements program in a less generous fashion than federal officials desire. Voice and exit thus aren't the only paths of influence for minorities. Minorities can also exercise agency in their ongoing quarrel with the center because they are often the center's agents. ${ }^{3}$

Retooling Hirschman's frame to include agency, then, doesn't just draw our attention to an underappreciated avenue of minority influence. It raises questions as to why voice and exit have entirely dominated constitutional theory-why scholars who are interested in minority empowerment have overlooked the role that administrative arrangements can play in furthering that goal. We are all aware that bureaucrats wield power when they administer a program-we call it the principal-agent problem. And we are all aware that the principalagent problem can be particularly acute in the context of a partially politicized, highly decentralized system like our own. But the productive possibilities associated with the principal-agent problem have been neglected by constitutional theory.

The notion of loyalty plays a role in explaining this neglect, though it isn't the type of loyalty that Hirschman had in mind.

2. This is an argument about the relationship between the center and the periphery. Here I'll focus on minorities' influencing national policy, but the same basic arguments work with regard to minorities who wish to influence state policy.

3. I thus use the term agency to refer to minorities' exercising control over the administration of national policy. I am intensely grateful to Tom Wolf for suggesting the formulation. 
Because we typically think of administrative arrangements in Weberian rather than Tocquevillian terms, we treat bureaucratic resistance as an act of disloyalty-as a problem to be solved rather than a feature to be celebrated. We laud federalism and the First Amendment because they ensure a healthy level of resistance to an overweening national power, but when minorities use their administrative muscle to challenge national policy from within, we worry about parochialism or lawlessness. We assume, in short, that the principal-agent problem is always a problem.

That is a mistake. Although the principal-agent problem certainly involves costs, these decentralized governing units constitute unique sites for minority influence. They blend features of voice and exit, offering minorities the decisionmaking control afforded by exit and the insider status associated with voice. Because agency gives minorities decisionmaking power within the federal system, it has unique implications for two of the most important projects undergirding much of constitutional theory: integrating a diverse polity and encouraging democratic debate.

This Lecture is organized as follows. Part I explores the marked continuities between Hirschman's frame and the strategies for empowering minorities that dominate constitutional theory. Part II explains why Hirschman's third category, loyalty, is all but ignored by scholars and uses it as a starting place for identifying a third type of minority influence: agency. Part III returns to the notion of loyalty and considers why Hirschman-and most constitutional theoristshave neglected this important avenue of minority influence. Part IV identifies some of the ways in which agency supplements, complements, and competes with voice and exit as a channel of minority influence.

Two caveats are in order. First, in sketching out these claims, I necessarily offer some broad generalizations about the state of constitutional theory. There are, of course, exceptions to every rule, as the footnotes make clear. Second, many of the phenomena I discuss fall along a continuum. ${ }^{4}$ For ease of exposition, I will sometimes speak in categorical terms. Although those terms roughly

4. For instance, in discussing conventional federalism, I talk about state officials as "outsiders" to the national scheme when, of course, they are differently situated than true outsiders, such as officials from another country. I nonetheless think the distinction is useful, as it provides a means for identifying the difference between, say, state officials administering state law and state officials administering federal law. 
capture the phenomena I'm describing at the level of generality I'm describing them, please keep in mind that these categories will inevitably blur at the margins and might disappear entirely if we kick the analysis up to a sufficiently high level of generality.

\section{EXIT AND VOICE}

In 1970 Hirschman penned his famous book, Exit, Voice, and Loyalty. The book starts with a puzzle: "why the Nigerian railways had performed so poorly" even in the face of "active competition" from trucks. ${ }^{5}$ Hirschman builds on his observations about firm behavior to offer a free-form, wide-ranging disquisition on the sources of institutional change-or, as his subtitle reads, on "responses to decline in firms, organization, and states." The book is itself an interesting window into scholarly norms; people just don't write like that any more. The idea that you could move from a Nigerian railroad to firms to political parties to states is a bit startling to anyone deeply steeped in current disciplinary norms.

In spite of-or perhaps because of - its wide-ranging, unbounded arguments, Hirschman's account has become ubiquitous. Whether or not you accept his fox-like asides, the hedgehog's point has held fast-that one can influence an institution by exercising either voice or exit. If one takes up Hirschman's firm example, ${ }^{6}$ for instance, his analysis runs as follows: If your preferred soup manufacturer began offering a flawed product, what would you do? You could take advantage of the consumer's exit option and buy a better soup from a competitor. Consumers' exiting would induce the management to change lest the company lose more revenue. Or you could exercise voice, complaining about the soup's shortcomings and pushing the company to adapt.

Hirschman's typology has proved to be especially useful in framing a variety of debates related to democratic design. As Hirschman observes, notions like exit and voice easily translate from the economic context to the democratic one. ${ }^{7}$ A voter, for instance, can push his political party to change by exiting - voting for the other party or just staying home. Or the voter can exercise voice,

\footnotetext{
5. HIRSCHMAN, supra note 1 , at 44 (emphasis omitted).

6. Id. at 3-4.

7. Id. at $17-19,70$.
} 
complaining about the party's positions in the hope of spurring reform. ${ }^{8}$

Unsurprisingly, Hirschman's account is often invoked when we think about democratic arrangements, particularly when we are trying to answer that core question in constitutional theory: What does a democracy owe its minorities? Voice and exit offer deeply intuitive categories for classifying the dominant modalities we use to analyze the democratic influence that minorities wield. We see it on the structural side of constitutional theory, and we see it on the rights side as well.

\section{A. Exit and Voice in Constitutional Theory}

Here's a highly stylized typology, one that is plainly debatable but offers at least one reasonable way to get traction on these issues. For those strange creatures who think more clearly with the help of a two-by-two matrix, here's what it looks like:

\section{Table 1. Mapping Constitutional Theory onto Hirschman's Categories}

\begin{tabular}{|c|c|c|}
\hline Rights & $\begin{array}{c}\text { Right to free } \\
\text { speech }\end{array}$ & Right of association \\
\hline Structure & $\begin{array}{c}\text { Diversity/voting in } \\
\text { a national election }\end{array}$ & $\begin{array}{c}\text { Federalism/voting } \\
\text { in a state election }\end{array}$ \\
\hline
\end{tabular}

1. Rights. Let's start with the rights side of the equation. It is easy to spot examples of voice and exit in the work of those who think about what rights a democracy owes its minorities. The right to free speech grants minorities voice-a chance to criticize national policy and perhaps to influence public debate. The First Amendment gives minorities a chance to be part of the national conversation. Forests have been felled in the name of accounts of this sort. Indeed, the marketplace of ideas-one of the major theories undergirding First Amendment doctrine-is premised on the idea that the right to speak

8. Id. at $30-33,69-70$. 
allows dissenters to affect ongoing debates. Minorities may be outnumbered in this debate, but at least they will be heard.

The First Amendment also offers minorities an exit option: the privacy afforded by the right to associate, which allows minorities to exit the public sphere for the private one in order to govern themselves (mostly) as they see fit.' Although this exit option has typically been cast as a source of protection for minorities, it also fits Hirschman's notion that exit constitutes a form of influence. If enough people leave the public for the private, the hope is that this exodus will cause policymakers to adapt. ${ }^{10}$ In some instances, exit also offers minorities a type of influence that Hirschman did not contemplate. It allows minorities to model an alternative policymaking vision to convince the center of its merits, or at least its viability. It is precisely when minorities are unhappy with the regime public governance has produced that they turn to private governance, where they are outside the system and can thus pursue their own utopias. The Amish are, of course, the canonical example, but there are examples everywhere. Parochial schools, for instance, show us what a religiously inflected education looks like. Private organizations favoring gay rights offer members of the LGBT community a different experience from that offered by a society that often discriminates against them. Private universities can adopt policies that public ones cannot. These alternative models are protected precisely because these associations are private and thus outside the government's reach. And minorities can pursue a different course precisely because they enjoy majorities within these private organizations - they are not outnumbered, as they are in the public sphere.

2. Structure. Exit and voice are also easy to spot on the structural side of constitutional theory. On the exit side, we have federalism. ${ }^{11}$

9. For an exploration of the relationship between exit and association that pursues different arguments than those offered here, see Evelyn Brody, Entrance, Voice, and Exit: The Constitutional Bounds of the Right of Association, 35 U.C. DAVIS L. REV. 821 (2002).

10. Think, for instance, about public schools. I draw this example from HIRSCHMAN, supra note 1 , at $45-47$.

11. See, e.g., Ilya SOMIn, DEMOCRACY AND POLITICAL IGNORANCE (forthcoming 2013) (on file with the Duke Law Journal); Richard A. Epstein, Exit Rights Under Federalism, 55 LAW \& CONTEMP. PRobs. 147, 149 (1992); Barry Friedman, Valuing Federalism, 82 MinN. L. REV. 317, 386-405 (1997); Clayton Gillette, The Exercise of Trumps by Decentralized Governments, 83 VA. L. REV. 1347, 1347-52, 1408-17 (1997); Daryl J. Levinson, Rights and Votes, 121 YALE L.J. 1286, 1355 (2012); John O. McGinnis \& Ilya Somin, Federalism v. States' Rights: A Defense 
At first glance, this claim might seem a bit startling because, if anything, we conventionally associate decentralization with voice rather than exit. ${ }^{12}$ The intuition is that by pushing decisions down from the national to the state (or local) level, we give individuals more of a chance to make their opinions known.

If one thinks about federalism's place in democratic theory, however, exit is a better way to describe it. ${ }^{13}$ That's because federalism is at least in part a theory about what a democracy should do with its minorities. It's a strategy for dealing with-even leveraging-diversity. All but one or two minor theories of federalism turn on the fact that national minorities constitute local majorities. States, for instance, are unlikely to constitute laboratories of democracy or facilitate Tieboutian sorting ${ }^{14}$ if the same types of people are making the decisions at the state and federal level. Similarly, ambition is unlikely to counteract ambition if state and national actors are united in their ambitions.

If one thinks of federalism as a strategy for explaining what a democracy owes its minorities, it becomes clear that most theories of federalism stand in loosely for an idea that the best way to protect minorities in a majoritarian system is to give them an exit option, making space for them to enact their own policies separate and apart from the center. ${ }^{15}$ That is why some think that the very definition of federalism requires state sovereignty, ${ }^{16}$ and most assume that it at least demands a fairly high level of informal autonomy for states. ${ }^{17}$

of Judicial Review in a Federal System, 99 Nw. U. L. REV. 89-105, 110-12 (2004); Ernest A. Young, The Rehnquist Court's Two Federalisms, 83 TEX. L. REV. 1, 60 (2004); cf. Jonathan R. Macey, Federal Deference to Local Regulators and the Economic Theory of Regulation: Toward a Public-Choice Explanation of Federalism, 76 VA. L. REV. 265, 273 (1990).

12. Thanks to Richard Briffault for offering this formulation of what he takes (correctly) to be the conventional account in constitutional theory.

13. Some of these arguments are explored in greater detail, albeit from a different angle, in Heather K. Gerken, Foreword, Federalism All the Way Down, 124 HARV. L. REV. 4, 11-28 (2010).

14. See generally Charles M. Tiebout, A Pure Theory of Local Expenditures, 64 J. PoL. ECON. 416 (1956).

15. Exit, of course, is partial in the federalism context. As I note above, minorities are partial outsiders in the federalism context. See supra note 4. A full-exit option would presumably involve some form of secession.

16. See, e.g., William H. Riker, Federalism: Origin, Operation, Significance 11 (1964); Frank B. Cross, The Folly of Federalism, 24 CARDOZO L. REV. 1, 19 (2002).

17. See, e.g., Malcolm M. FeEley \& EdWARd Rubin, Federalism: Political IDENTITY AND TRAGIC COMPROMISE 12 (2008); Bradford R. Clark, The Procedural Safeguards of Federalism, 83 Notre DAME L. ReV. 1681, 1681 (2008); Larry D. Kramer, Putting the Politics Back into the Political Safeguards of Federalism, 100 COLUM. L. REV. 215, 222 (2000); Larry 
Here, it's useful to compare federalism to its First Amendment cognate, the right to associate. We protect the right to associate precisely because we want to ensure that groups can create their own utopias. Autonomy creates space for disuniformity and dissent. The notion of autonomy has just as much pull on the structural side. We value it because it prevents the national majority from imposing its preference on local majorities. Just as the First Amendment protects minorities' exit option on the rights side, sovereignty and autonomy protect minorities' exit option on the structural side.

Federalism's emphasis on exit is also evident in scholars' failure to push federalism theory all the way down to juries, school boards, zoning commissions, state agencies, locally elected sheriffs, and the like. ${ }^{18}$ Given its focus on minority-dominated governance, you might think that federalism would naturally look to local, substate, and sublocal institutions as sites of minority rule. After all, given that most states are fairly populous, minorities have a better chance of ruling at the local level. But while some scholars have argued that federalism should extend to cities, ${ }^{19}$ they have not carried that insight to its logical conclusion and included special-purpose, administrative units within federalism's ambit. ${ }^{20}$

The reason for this neglect, in my view, is the salience of exit to federalism theory. These administrative units seem unlikely sites for "Our Federalism" to anyone influenced by an exit account. An exit account pivots off an image of minorities' presiding over their own empires rather than administering someone else's; it focuses on the power of minorities to put in place policies that the center cannot touch. Administrative units are, almost by definition, not sites for exit. They are part of the system, not outside of it. While minorities wield control, the power they wield is not their own. When minorities set policy within these administrative units, they aren't setting policies

Kramer, Understanding Federalism, 47 VAND. L. REv. 1485, 1513 (1994); D. Bruce La Pierre, The Political Safeguards of Federalism Redux: Intergovernmental Immunity and the States as Agents of the Nation, 60 WASH. U. L.Q. 779, 786 (1982); Andrzej Rapaczynski, From Sovereignty to Process: The Jurisprudence of Federalism After Garcia, 1985 SUP. CT. REV. 341, 416; Ernest A. Young, Two Cheers for Process Federalism, 46 VILL. L. REV. 1349, 1349, 1358 n.42, 1385 (2001).

18. Gerken, supra note 13, at 22.

19. See, e.g., Richard Briffault, "What About the 'Ism'?" Normative and Formal Concerns in Contemporary Federalism, 47 VAND. L. REV. 1303, 1304 (1994). Many have extended the insights of federalism to cities. See id. at 1304-05, 1310-16 (collecting sources).

20. Gerken, supra note 13, at 22-27. 
that are shielded from the center; they are setting policies for the center.

One might respond that the neglect of these administrative units has nothing to do with exit. Federalism is, by definition, about states; it's a definition rooted in the text and history of the Constitution. But that response is too simple. For better or for worse, federalism theory has moved well beyond arguments about the text and history of the Constitution, arguments that would naturally confine theories of federalism to states. Instead, federalism theory now largely turns on a set of functional justifications for valuing minority rule. ${ }^{21}$ And if one thinks only about the functional, it's quite natural to think about federalism's values for institutions below the state level. That's why scholars have already proposed grouping cities with states in thinking about federalism. ${ }^{22}$ But although scholars have moved beyond states, they have stopped with cities. ${ }^{23}$

That's not a coincidence. Cities are the one other institution that can conceivably offer a robust exit option. ${ }^{24}$ Like states, they are sites of general jurisdiction-units where we can imagine minorities' ruling themselves, separate and apart from the center. Like states, cities enjoy some level of formal and informal autonomy, ${ }^{25}$ so that

21. Federalism, for instance, is thought to promote choice, competition, participation, experimentation, and the diffusion of power. E.g., Gregory v. Ashcroft, 501 U.S. 452, 458-59 (1991); see also Akhil Reed Amar, Five Views of Federalism: “Converse-1983” in Context, 47 VAND. L. REV. 1229 (1994); Lynn A. Baker \& Ernest A. Young, Federalism and the Double Standard of Judicial Review, 51 DUKE L.J. 75, 136-39 (2001); Steven G. Calabresi, "A Government of Limited and Enumerated Powers": In Defense of United States v. Lopez, 94 MICH. L. REV. 752, 774-79 (1995); Deborah Jones Merritt, The Guarantee Clause and State Autonomy: Federalism for a Third Century, 88 CoLUM. L. REV. 1, 3-10 (1988); Young, supra note 11, at 52-63; Michael W. McConnell, Federalism: Evaluating the Founders' Design, 54 U. CHI. L. REV. 1484, 1491-1511 (1987) (reviewing RAOUL BERGER, FEDERALISM: THE FOUNDERS' DESIGN (1987)). Some believe we reel these arguments off too easily. See Barry Friedman, Valuing Federalism, 82 MINN. L. REV. 317, 318-19 (1997).

22. Richard Briffault makes precisely this point. Briffault, supra note 19, at 1305; see also Mark C. Gordon, Differing Paradigms, Similar Flaws: Constructing a New Approach to Federalism in Congress and the Court, 14 YALE L. \& POL'Y REV. 187, 218 (1996).

23. Richard Briffault is the exception, as he has written on economic institutions at the sublocal level. See generally, e.g., Richard Briffault, A Government for Our Time? Business Improvement Districts and Urban Governance, 99 COLUM. L. REV. 365 (1999); Richard Briffault, The Rise of Sublocal Structures in Urban Governance, 82 MINN. L. REV. 503 (1997).

24. How robust an exit option they offer is up for debate. See, e.g., Richard Briffault, Our Localism: Part I-The Structure of Local Government Law, 90 COLUM. L. REV. 1, 5 (1990); Gerald E. Frug, The City as a Legal Concept, 93 HARV. L. REV. 1057, 1069-72 (1980).

25. Many cities enjoy "home rule" provisions whose utility is a subject of intense debate in local government law. Compare David J. Barron, Reclaiming Home Rule, 116 HARV. L. REV. 2257, 2263 (2003), David J. Barron \& Gerald E. Frug, Defensive Localism: A View of the Field 
minorities who govern them can meaningfully be understood as presiding over empires of their own. And notice what remains outside of federalism theory. It's the substate and sublocal institutions that constitute states and cities-juries, school committees, zoning commissions, locally elected prosecutors, and the like. These are the institutions where exit is not to be had.

As with the right to associate, federalism is not just a source of protection for minorities. It also offers minorities a path of influence. First, consistent with Hirschman's account, minorities can signal their unhappiness with national policies by pursuing different policies at the state level. Second, minorities can dissent by deciding ${ }^{26}$ they can offer a real-life instantiation of their ideas by, say, licensing same-sex couples to marry or enacting strict abortion laws.

We also see the voice model on the structural side. It's the diversity model - an institutional-design strategy often invoked by the nationalists, who are deeply skeptical of federalism. Here again, this may seem like a startling claim at first. Diversity and federalism are not typically paired in this fashion. But, again, if one views these institutional design strategies through the lens of democratic theory, diversity is properly understood as a strategy that grants minorities "voice" in the decisionmaking process.

Here I think the argument is easiest to understand if we back into it and start by thinking in institutional terms about what a conventional nationalist thinks a democracy owes its minorities. What is federalism's institutional competitor? Proponents of federalism and nationalism both favor a basic baseline of rights. But when it comes to structure, nationalists - disgusted with federalism's past—gravitate to an idea familiar to all of us: the diversity paradigm. The idea is simple and intuitive: that decisionmaking bodies ought to mirror the population from which they are drawn-they ought to look like America, to use Bill Clinton's favorite phrase.

Diversity is the rough cognate to the voice model. It offers minorities a subset of seats or votes on every decisionmaking body. It thus gives minorities the opportunity to make their views heard, even if they can't control the outcome. Indeed, proponents of diversity

from the Field, 21 J.L. \& POL. 261, 261-62 (2005), and Frug, supra note 24, at 1059-60, with Briffault, supra note 24, at 7.

26. See generally Heather K. Gerken, Dissenting by Deciding, 57 STAN. L. REV. 1745 (2005). 
often invoke the "dignity of voice" in making the pitch for including minorities on various decisionmaking bodies. ${ }^{27}$

3. The Voting Conundrum. One might, of course, balk at the way I've classified these structural arrangements. The right to speak and the right to associate map pretty neatly onto Hirschman's categories. But structural arrangements fit more loosely. While Hirschman imagined that voters could "exit" their party by voting for a competing party, one might still insist that voting under the diversity model shouldn't be equated with "voice." After all, when you vote, you are part of the decisionmaking process, not just complaining about it.

Fair enough. The typology is, as I said, a loose one, and Hirschman himself didn't identify exactly how voting fits into his scheme. If you think voting absolutely disqualifies structural arrangements from being included in Hirschman's typology, you can stop here. But there's good reason for a bit of flexibility here. While voting is a pervasive feature on the structural side, there are different variants of voting, and Hirschman's scheme helps us map them.

One can, for instance, make a sensible case that, at least for political minorities, ${ }^{28}$ voting under the diversity paradigm looks a good deal like voice. Political minorities are, by definition, the losers when a national vote is taken. If political minorities didn't vote at all, the decision would still get made, and it would still be a decision they oppose. Voting in this context is a form of protest - a way to signal unhappiness with the decision. This signal may influence future debates, but it won't affect the decision on the table. ${ }^{29}$

Similarly, voting under federalism looks a lot like exit. As I noted above, we conventionally think that pushing an issue down to the state level gives minorities more "voice" over the decision. When

27. See, e.g., ANNe Phillips, The POlitics of Presence 79 (1995); Jane Mansbridge, Should Blacks Represent Blacks and Women Represent Women? A Contingent "Yes," $61 \mathrm{~J}$. POL. 628, 628 (1999); Charles Taylor, The Politics of Recognition, in MulticulturalisM: EXAMINING THE POLITICS OF RECOGNITION 25, 25 (Amy Gutmann ed., 1994).

28. To be sure, one might resist the idea that the classification may work only for political minorities. Hirschman's arguments are cast in individualist terms. To the extent he contemplates group action, he assumes that voters and consumers will take a roughly similar view of the problem. The variation on which Hirschman focuses is the different ways people react to an agreed-upon problem.

29. Unless, of course, we are talking about smaller decisionmaking bodies, where dissenters may trade away their dissenting votes in exchange for compromises from the majority. Gerken, supra note 26, at 1746-47. 
people use the term voice, they are really thinking about influence. But Hirschman's key insight is that we can distinguish between avenues of influence. And there is a crucial difference between voting and "voting with one's feet"- between the diversity model and federalism. Under the diversity model, minorities inevitably cast a losing vote. Federalism, in contrast, gives minorities the chance to win-to form local majorities and exercise a decisive vote rather than merely "voice" their concerns. What some term "voice" is better understood as control.

Note, however, that under conventional models of federalism minorities don't exercise control over national policy; they exercise control over state policy. The price of the power to control is outsider status. Unlike the diversity model and the right to free speech, it's a form of influence available only outside the national sphere. It thus bears a close resemblance to the right to associate, which grants minorities the power to govern themselves only when they move outside the public sphere to the private one.

$$
* * *
$$

No matter where we look, then, voice and exit capture the dominant modalities for thinking about what avenues of influence a democracy owes its minorities. While Hirschman didn't invent these ideas, he offered a deeply intuitive framework for sorting and comparing them. Little wonder, then, that Hirschman's categories are so often invoked by constitutional theorists.

\section{RETHINKING HIRSCHMAN'S FRAMEWORK}

\section{A. What About Loyalty?}

For all of Hirschman's success with voice and exit, his third category-loyalty - turned out to be a bust. Just ask yourself this: Can you even remember what Hirschman said about loyalty? In an informal survey of colleagues, I've found that even those who can recite other parts of the book, chapter and verse, often have only the vaguest of ideas about what Hirschman said about loyalty. The same holds true of the scholarly literature. The vast majority of citations to Hirschman emphasize exit and/or voice, as if the third word of the book's title had been excised.

Hirschman was admittedly somewhat imprecise in his formulation. But I think our collective amnesia is due largely to the 
fact that Hirschman cast loyalty as a cushion against hasty exits. ${ }^{30}$ The notion of loyalty helped Hirschman think about why everyone doesn't just take the easy exit option-why some cling to a brand or an organization in the hope that voice will eventually put it back on the right track.

You can see why Hirschman, the economist, might worry. As long as you know there's a decent competitor out there, exit is usually easier-or at least more certain - than voice. Animating Hirschman's account of loyalty is a worry about what happens when an organization screws up and exit is easy. ${ }^{31}$ Customers might exit en masse when a firm makes its first bad product, and a perfectly good company would never get a chance to recover. You can see the worry on the political side as well (though here it seems less realistic). If exit is too prevalent, running one lousy candidate will sink the party, leaving nothing in its wake. Loyalty raises the cost of exit and thus cushions the potential blow that exit can inflict.

I have no quarrels with Hirschman's account of loyalty. But I think the reason people forget this part of the book is that loyalty, in Hirschman's view, wasn't an avenue of influence; it was a cushion against it.

Although Hirschman thought loyalty would dampen influence, one can find stray references in his work that hint of a quite different possibility-the possibility that there might be another avenue of influence beyond voice and exit. If you read Hirschman closely, he drops interesting observations about the relationship between loyalty and influence. He notes in passing that those most loyal to the organization are most likely to have their voices heard by its management. ${ }^{32}$ At some points in the book, he vaguely links loyalty to membership and decisionmaking-momentarily moving away from the passive, consumer-oriented account he deploys in most of the book-and ever so briefly contemplates that members might have some direct role in the decisionmaking process. ${ }^{33}$

Admittedly, the bits and pieces I'm discussing aren't really what Hirschman meant by loyalty, and his observations along these lines are fragmentary and largely unexplored. But they nonetheless point up the possibility of taking Hirschman's framework in a different

\footnotetext{
30. See HirsChMAN, supra note 1 , at 78 .

31. Id. at 79 .

32. See id. at 77 .

33. Cf. id. at $98-105$.
} 
direction, one that pivots off notions like loyalty, membership, and belonging in thinking about channels of democratic influence.

\section{B. A Third Avenue of Influence: Agency}

1. National Minorities As National Agents. In order to think about this third avenue of minority influence, we need to set aside the notion that dominates Hirschman's thinking. He writes as if everyday citizens were situated politically much as they are economicallyatomized, largely passive consumers of whatever political products are offered to them. Hirschman imagines voters having little to do in the democratic process save accept or reject the positions forged by political elites.

What Hirschman's account misses is that citizens don't just vote on competing visions of what national policy ought to look like. In our highly decentralized and partially politicized bureaucracy, citizens help make national policy. Citizens do so directly when they serve on juries, sit on locally oriented school boards and zoning commissions, or function as "street-level bureaucrats." ${ }^{34}$ And they do so indirectly by electing state and local politicians who serve a nominally bureaucratic role and thus can staff more (or less) cooperative agencies to carry out federal policy.

The fact that citizens implement federal policy indirectly or directly wouldn't much matter to those concerned with the influence minorities wield in a democracy but for one fact: residential patterns in this country are lumpy. In many places, national minorities constitute local majorities. This means that in some parts of the system, minorities wield control over the national policymaking apparatus, giving minorities an opportunity to administer the very federal policies with which they disagree.

Minorities thus have lots of opportunities for setting policy rather than merely complaining about it-lots of opportunities for controlling federal law from within rather than challenging it from without. Precisely because minorities serve as the center's agents,

34. MiCHAEL LIPSKY, STREET-LEVEL BUREAUCRACY: DILEMMAS OF THE INDIVIDUAL IN Public SERVICES 3 (1980) (emphasis omitted).

35. Note the parallel here. As with exit and voice, agency takes two forms: one involves direct participation (serving on a jury or school board), and the other involves representation (voting for someone to administer federal law on one's behalf). So, too, voice and exit involve direct participation (the right to speak or form a private association) and representation (voting under the diversity paradigm or under federalism). 
minorities can do more than exercise voice or exit when they disagree with the center's policies: they can exercise agency.

Our system is rife with examples of one set of decisionmakers setting policy at the center and another, quite different, set of decisionmakers implementing it at the periphery. These decisionmaking bodies are usually charged with implementing a legislative or executive mandate-a jury applying the law enacted by Congress, a school board implementing the policy set by the Department of Education. The chance to register disagreement through a decision-to "dissent by deciding" ${ }^{36}$ - emerges ad hoc, either by the grace of the majority or out of practical necessity. Juries, for instance, can render a decision only within a range set by the legislature. State environmental agencies carry out duties that the federal government assigns to them. School boards implement policy within a range set by a central policymaker.

Opportunities for agency do not, however, depend entirely on the willingness of the majority to cede some discretion to the lowerlevel decisionmakers. Disaggregated institutions are a solution to the problem of mass governance. Central decisionmakers must give some discretion to lower-level decisionmakers to interpret and implement the majority's decrees. Juries, school boards, city governments, statecreated bureaucracies-all serve as agents of the national government. And in the gap between the policy and its administration often lies a sizeable amount of discretion for those on the periphery, the opportunity to regulate as they see fit, to "edit" the policy that they lack the power to "authorize. ${ }^{, 37}$ In these innumerable nooks and crannies, there are many places where geographically concentrated minorities can exercise power. Residential segregation is something we often mourn in this country, and with good reason. But in a decentralized system like our own, these clusters also provide minorities with an avenue of influence.

36. Gerken, supra note 26, at 1749.

37. I borrow these terms from Philip Pettit. See Philip Pettit, Republican Freedom and Contestatory Democratization, in DemocracY's VALUE 163, 164 (Ian Shapiro \& Casiano Hacker-Cordón eds., 1999). Pettit, however, uses them in a slightly different context, discussing the need to grant electoral minorities the opportunity to "edit" the law by contesting it in an acceptably neutral process - such as a proceeding before a judge, a jury, or an administrative agency - and thereby to vindicate what he terms a "contestatory" or "oppositional" model of democracy. Id. at 183-85. His conception of dissent focuses more on elites and less on a populist conception in which the people speak for themselves. 
Cooperative federalism is thus paired with uncooperative federalism. ${ }^{38}$ Cooperative localism is paired with local resistance. ${ }^{39}$ The people who are nominally state and federal bureaucrats include state legislators and everyday citizens, decisionmakers who pair expertise with politics, and those whose jobs are all but entirely political. Even in highly centralized, highly technocratic federal bureaucracies, we see state and local variation in carrying out what otherwise seem like routinized policy jobs. ${ }^{40}$ The rebellion of the street-level bureaucrat is hardly confined to the street.

In each of these examples, the decisionmakers in question serve two masters, not one. They are nominally the agents of the federal government. But they are differently composed and thus draw their power from a different power base than those at the center-a randomly drawn jury carrying out a congressional command, local school officials carrying out the president's education policy, a bureaucracy created by a state whose political leadership is hostile to the federal mandate.

One might argue that this sort of decisionmaking power isn't really a form of influence because, in sharp contrast to voice and exit, agency involves minorities controlling rather than merely influencing decisions as to how national policy gets implemented. But remember that the decision over which they exercise control isn't "the" decision. As I describe in greater detail below, minorities aren't changing national policy; they are changing parts of it, with the aim of influencing national policy in its entirety going forward. Indeed, at some level of generality, agency promotes minority influence in much the same way as voice and exit do: it allows minorities to signal dissent and model an alternative approach. If parents can influence policymakers by exiting the public school system, bureaucrats can do the same by opting out of a federal program. If minorities can influence the national debate with an editorial, they can do the same

38. See Jessica Bulman-Pozen \& Heather K. Gerken, Uncooperative Federalism, 118 YALE L.J. 1256, 1259 (2009).

39. See Nestor M. Davidson, Cooperative Localism: Federal-Local Collaboration in an Era of State Sovereignty, 93 VA. L. REV. 959, 960 (2007).

40. See, e.g., Jerry L. Mashaw, Accountability and Institutional Design: Some Thoughts on the Grammar of Governance, in PUBlic ACCOUNTABILITY: DESIGNS, DilemMAs AND EXPERIENCES 115, 142-44 (Michael W. Dowdle ed., 2006); John T. Scholz, Jim Twombly \& Barbara Headrick, Street-Level Political Controls over Federal Bureaucracy, 85 AM. POL. SCI. REV. 829, 831-32 (1991); see also LIPSKY, supra note 34, at 13. 
by engaging in jury nullification or licensing same-sex couples to marry.

2. Beyond Voice and Exit. If you think that minorities' administrative roles offer them channels for influencing national policy, it's not hard to imagine why minorities might find these channels valuable. Think about the options that are otherwise on the table. On the structural side, constitutional theory offers us a choice between voice and exit. When you are part of the national system, the diversity paradigm (roughly) governs. ${ }^{41}$ The political power minorities wield is, at least in theory, roughly proportional to their share of the national vote. When we lay the diversity model down next to its main institutional competitor, federalism, one can immediately see what's odd about this strategy for empowering minorities: diversity relentlessly reproduces in governance bodies the same inequalities that minorities experience pretty much everywhere else. On any politically salient issue on which the minority and majority routinely divide, minorities voting in national elections are destined to be political losers.

You can see, then, the attractions of the exit option that federalism offers. Federalism gives minorities the chance to be the majority. It gives them more than influence at the local level; it gives them control. But note that this benefit comes with a price. Minorities must exit the national system - they must work at the state level-in order to exercise that power. Their power is protected, in fact, precisely because they are outsiders; sovereignty and autonomy are keyed to it. Indeed, sovereignty and autonomy arguably reify minorities' outsider status. The decisions that minorities render are protected precisely because they are the decisions of a state polity, not "the" national polity. Under federalism's exit option, minorities get to wield governmental authority, but they don't get to wield it on behalf of the national government.

Roughly the same set of trade-offs obtains on the rights side of the equation. Minorities have the right to speak and to petition their government. When they do so, however, they lack the ability to control the decisionmaking process. That sort of power comes, if at all, only when minorities take an exit option and create a private

41. I used the weasel word roughly because we elect congressional representatives from states and districts and the president via the electoral college, which ensures that particular minorities do better than their numbers would otherwise suggest. 
association to govern themselves along the lines the majority has rejected. And the decisions of that association are protected precisely because they are private. If minorities begin to wield public authority, they also begin to lose the protections the First Amendment provides. ${ }^{42}$

If one begins to compare the relative costs and benefits of voice and exit, one can see that there may be instances in which political minorities might like to wield the power exit confers-control, not just voice-without having to exit to the state or to the private sphere. Minorities might sometimes prefer to help administer the federal empire than administer an empire of one's own, to serve as a policymaking insider rather than an autonomous outsider, a critic from within rather than a dissenter from without.

As with exit and voice, there is a price to influence that takes this form. Agency gives minorities the power to make decisions, but-in sharp contrast to the exit model-those decisions are not shielded from reversal. The center can-and sometimes does-overrule the periphery.

All three channels of influence involve trade-offs. Voice offers insider status without majority status. Exit does the reverse. Agency offers both majority and insider status, but the power that minorities wield is that of the servant rather than the sovereign, the agent rather than the principal. The decisions minorities make in an integrated policymaking regime are thus not protected from reversal. ${ }^{43}$

For those who prefer a matrix, here's a rough breakdown:

42. The canonical case is Rust v. Sullivan, 500 U.S. 173 (1991).

43. Certain types of jury verdicts, such as "not guilty" verdicts in criminal cases, are an exception. 
Table 2. Mapping Exit, Voice, and Agency

\begin{tabular}{|c|c|c|c|}
\hline & Exit & Voice & Agency \\
\hline Status & Outsider & Insider & Insider \\
\hline $\begin{array}{c}\text { Decisionmaking } \\
\text { control/majority } \\
\text { status }\end{array}$ & Yes & No & Yes \\
\hline $\begin{array}{c}\text { Protection from } \\
\text { reversal }\end{array}$ & Yes & Yes & No \\
\hline
\end{tabular}

One might, of course, think that the power of the servant isn't a form of power at all. What good does it do to enact a policy if it is not shielded from reversal? I spend a lot of time in a recent paper arguing that the power of the servant is actually quite important. ${ }^{44}$ Just ask any administrative-law scholar, or indeed, anyone who has written on the principal-agent problem. The power of the agent is different from that of the principal-agency is different from exit—but it is power nonetheless.

I won't offer a full survey here ${ }^{45}$ but let me sketch a couple of reasons why the power of the servant matters-why agency can sometimes offer minorities a robust channel of influence. One reason that servants are powerful is that the center depends on them to get anything done. Members of Congress and the president can't personally ensure that every one of their policies is implemented perfectly. They can exercise their political capital here and there, but they have to pick and choose, and ultimately they are dependent on others to put their policies into place. That leaves room for minorities to push back against federal mandates.

44. See Gerken, supra note 13 , at 33-44.

45. For more developed arguments, see id. at 33-44, 68-71; and Bulman-Pozen \& Gerken, supra note 38 , at $1265-71$. 
Servants are also powerful precisely because they are integrated in the system rather than standing outside of it. State and local officials can take advantage of the web of connective tissues that bind the periphery to the center. Moreover, insider status gives state and local officials standing -in the colloquial sense-to challenge the center. They can voice dissent from within the system, base their claims on shared expertise and experience, and cast that dissent in terms readily comprehensible to the relevant decisionmakers. They thus resemble Michael Walzer's "connected critics." ${ }^{46}$ Walzer insists that an effective critic must be "[a] little to the side, but not outside" of the community she challenges, as her ability to dissent effectively will depend on her ties to the community. ${ }^{47}$ So, too, minorities who exercise agency are a little to the side but not outside the system and thus capable of dissenting in a fashion that true outsiders cannot.

Finally, servants may be better able to provoke a response from the center than the prototypical dissenter, precisely because they are inside rather than outside the system. It's often relatively easy to ignore a contrary policy when that policy is put in place elsewhere. It's harder to ignore outliers when they are in your midst. California and the United States can ignore the Netherlands when it licenses same-sex couples to marry, but they can't do the same when the City of San Francisco does so. When minorities exercise agency, they thwart the uniform administration of federal law and create the risk that other federal "agents" will demand a similar exemption. It is also irritating to see one's own monies hijacked to challenge the very policy those funds are supposed to promote. As Jessica BulmanPozen and I observe elsewhere, "[m] odus vivendi is less palatable when funded out of your own pocket." ${ }^{48}$

\section{WHY THE GAP IN CONSTITUTIONAL THEORY? THE COMPLEXITIES OF LOYALTY}

If one accepts the notion that agency represents a third path of minority influence, the natural question is why it's been neglected by constitutional theorists. We have a field devoted to cooperative

\footnotetext{
46. Michael WALZER, INTERPRETATION AND SOCIAL CRITICISM 39 (1987).

47. Id. at 61 .

48. Bulman-Pozen \& Gerken, supra note 38, at 1287; cf. Ronald Reagan, Remarks at the New Hampshire Republican Primary Debates (Feb. 23, 1980) ("I am paying for this microphone ... !"); State of the Union (Liberty Films 1948) ("Don't you shut me off; I'm paying for this broadcast." (quoting Spencer Tracy's character)).
} 
federalism but we neglect uncooperative federalism. We have a field devoted to thinking about dissent from without but we neglect dissent from within. ${ }^{49}$ We think a great deal about the role minorities play in making national policy but not about the role they play in implementing national policy. ${ }^{50}$

\section{A. Minding the Gap}

We don't just neglect this avenue of influence; we disparage it. We call it the principal-agent problem and treat it as a nuisance to be solved rather than a phenomenon to be celebrated. We romanticize the solitary dissenter, but we have no celebratory term for what happens when local dissenters join together to put their policies in place. Instead, the only terms we have are negative. We term those places where dissenters dominate as "lawless" or "parochial.",51

This isn't just a nominalist claim; it's a substantive one. Why is it that those who care about dissent have largely ignored minoritydominated governance in thinking about the question of minority empowerment? Why do they stick with a rights-based account of what a democracy owes to its minorities? Dissenters have long used local concentrations of power to build support for their positions. For example, much of the work on gay rights has been done at the local level. The Supreme Court has even given us a case to think about the issue. ${ }^{52}$ To top it all off, theorists of dissent do think about the values associated with minority-dominated institutions in the private sphere,

49. First Amendment scholars have thought about the rights of whistleblowers, of course, as well as the rights of government employees. See generally, e.g., Rosalie Berger Levinson, Silencing Government Employee Whistleblowers in the Name of "Efficiency", 23 OHIO N.U. L. REV. 17 (1996); Randy J. Kozel, Reconceptualizing Public Employee Speech, 99 NW. U. L. REV. 1007 (2005); Gia B. Lee, First Amendment Enforcement in Government Institutions and Programs, 56 UCLA L. REV. 1691, 1766-71 (2009); Helen Norton, Constraining Public Employee Speech: Government's Control of Its Workers' Speech To Protect Its Own Expression, 59 DUKE L.J. 1 (2009); cf. supra note 42. They are insiders in some senses, but not in the sense I describe here (individuals who are such deeply involved insiders that they control the levers of power).

50. Administrative law scholars have done a good deal of work on this topic, although most focus on different issues than those discussed here.

51. Nestor M. Davidson offers the term "lawless localities" in his efforts to critique it. Davidson, supra note 39, at 1017-26. For a similar critique challenging the "usual parochialism story" that depicts localities as hostile to religious minorities, see Richard C. Schragger, The Role of the Local in the Doctrine and Discourse of Religious Liberty, 117 HARV. L. REV. 1810, 1815 (2004).

52. Romer v. Evans, 517 U.S. 620 (1996). The case has been cast in these terms by scholars of local government law, but not by constitutional theorists. 
where work on associational rights and pluralism places great emphasis on what a democracy owes its minorities. So why don't these scholars think about minority-dominated governance"pluralism" within the public sphere-as yet another tool for minority empowerment?

Or consider federalism, the one theory in constitutional law that depends on, even glories in, the notion that national minorities constitute local majorities. ${ }^{53}$ Federalism, as noted above, is so closely tied to an exit account that it mostly neglects the administrative arrangements I describe here-those in which state and local officials implement federal law in an integrated policymaking regime. And even when scholars turn to these administrative arrangements, the term we use to describe them is cooperative federalism.

Here again, this isn't just a nominalist claim. There is a good deal of work on "cooperative" federalism - the institutional arrangements in which a complex amalgam of local, state, and federal officials regulate together. As the moniker suggests, however, the work on cooperative federalism dwells almost entirely on the happy dimensions of federal-state regulation. Scholars of cooperative federalism emphasize the ways in which joint regulation promotes mutual learning, healthy competition, and useful redundancy. These scholars neglect the uncooperative dimensions of cooperative federalism and the democratic elements of these bureaucratic arrangements. As a result, the work in federalism theory that does focus on political outliers and resistance-the role federalism plays in checking an overweening national government and promoting dissent-is almost entirely confined to conventional federalism theory, where exit is the dominant account. ${ }^{54}$

Federalism scholarship doesn't just neglect uncooperative federalism; it also neglects uncooperative localism. Federalism scholars, after all, are the rare academics who don't always think that the principal-agent problem is a problem. To the contrary, they celebrate the opportunities for rebellion and contestation that

53. Although election law focuses on minority-majority districts, the main intellectual push behind them is that they are the best means for creating a statistically integrated legislature. In the words of Richard Pildes, "[t]he very theory of districted elections . . . is that democratic institutions are best designed by . . . fragmenting majoritarian domination. Districted elections empower local minorities who would otherwise be swallowed up in a system not self-consciously designed to ensure some representation of their interests." Richard H. Pildes, Diffusion of Political Power and the Voting Rights Act, 24 HARV. J.L. \& PUB. POL'Y 119, 124 (2000).

54. See supra notes 11-22 and accompanying text. 
decentralization provides. And it's just a hop, skip, and a jump from theorizing about states to theorizing about the local, substate, and sublocal institutions where dissenters are far more likely to have such opportunities. As a result, federalism scholars miss many an opportunity for intellectual arbitrage-the chance to connect their work on minority-dominated governance to work done by their colleagues on the rights side of constitutional theory.

\section{B. Agency and Disloyalty}

Why, then, do scholars neglect this third avenue of minority influence? It's presumably because the notion of agency would require us to celebrate chaos and dissensus within a bureaucratic system, something that sits uneasily with most of us. When the subject is the administrative state, Weber is foremost in our minds, not Tocqueville. When we talk about democracy, we routinely celebrate the idiosyncratic dissenter, the nobility of resistance, the glory in getting things wrong, and the wild patchwork of views that make up the polity. When thinking about administrative arrangements, we laud bureaucratic efficiency, worry about local incompetence, and have a strong impulse to quash local rebellion. What is celebrated in the democratic realm is condemned in the bureaucratic one.

If one were to press the point, surely most would admit that it's useful to have institutionalized channels for dissent within federal administrative agencies. ${ }^{55}$ Nonetheless, the notion that local or state agents might hijack federal policy in pursuit of their own agendas smacks of disloyalty. It's one thing for dissenters to speak against the center; it's quite another for them to use power the center gave them to thwart its wishes.

This conception of loyalty is more robust than the one offered by Hirschman, who mostly thought of loyalty as a vaguely irrational impulse to cling to what one knew. ${ }^{56}$ It is rooted in a Weberian vision of bureaucracy, one that suggests (reasonably enough) that the principal has the right to command the agent he's hired to carry out

55. See, e.g., Neal Kumar Katyal, Internal Separation of Powers: Checking Today's Most Dangerous Branch from Within, 115 YALE L.J. 2314, 2317 (2006) ("A critical mechanism to promote internal separation of powers is bureaucracy ... . [B]ureaucracy creates a civil service not beholden to any particular administration and a cadre of experts with a long-term institutional worldview.").

56. HIRSCHMAN, supra note 1 , at 38,81 . 
his bidding. It's a notion that privileges hierarchy, uniformity, and clear lines of authority.

This notion of loyalty exerts such a strong hold on us that we view internal resistance with suspicion even when it's entirely lawful. After all, a good deal of the conduct I would term "agency" easily fits within legal bounds, and yet we still react to it with distaste. Sometimes we authorize administrative units to dissent. For instance, it's lawful for juries to nullify. Similarly, we often grant states licenses to experiment. That's what the Reagan administration did for states like Michigan and Wisconsin, whose governors then used federal dollars to create "welfare to work" systems with the explicit aim of overturning the existing regime. ${ }^{57}$ In other instances, political outliers simply take advantage of a gap in the federal mandate and use that decisionmaking space to take federal policy in a direction the center does not anticipate. California, for instance, has taken advantage of gaps in the federal regulations to enact stronger environmental regulations than federal officials would prefer. $^{58}$ State officials less enamored of environmental regulation have done the same, taking federal policy in a deregulatory direction. ${ }^{59}$

The fact that we intuitively equate agency with disloyalty despite its lawfulness may also reveal how deeply rooted exit and voice are in our vocabulary. We have a firm sense of what the "loyal opposition" is supposed to do-speak out (voice) or get out (exit). That's why activities that don't fit neatly within the exit/voice paradigm-like civil disobedience-can cause us to turn analytic cartwheels.

\section{The Loyal Opposition and Partial Loyalty}

Concepts like the "loyal opposition" and civil disobedience can also help us sort out how to think about acts of agency. Let's start with those forms of agency that are plainly legal. As noted above, many forms of agency can fairly be understood as the actions of the law-loving dissenter. ${ }^{60}$ Much as dissenting speech is licensed by the First Amendment, these forms of agency are either explicitly licensed by the majority or, at least, left open to minorities in the exercise of their legally conferred discretion. In these instances, minorities can

\footnotetext{
57. For a description, see Bulman-Pozen \& Gerken, supra note 38, at 1274-76.

58. For more detail, see $i d$. at 1276-78.

59. See id. at 1277.

60. Thanks to Jiewuh Song for suggesting the phrase.
} 
both challenge the majority and yet act on its behalf; they can contest the law at the same moment that they comply with it.

Minorities who exercise agency, then, are acting much like members of the loyal opposition; they share the majority's basic commitments but differ as to how those commitments ought to be carried out. And while they are, in fact, challenging the majority, they are also serving it by ensuring that the polity is thinking through its decisions and taking into account all the relevant concerns. That is precisely why we think the opposition is loyal; we understand contestation to serve an important role in promoting sensible decisions and in fostering a healthy democracy. Little wonder, then, that many theories in constitutional law are keyed to our need for a loyal opposition. The First Amendment creates room for the loyal opposition in the private sphere by protecting the right to speak and associate. Federalism and diversity make space for the loyal opposition in the legislative sphere. And agency makes space for the loyal opposition in the administrative sphere.

The strongest forms of what I term "agency" do indeed involve genuine rebellion-a deliberate effort to thwart federal law, or at least implement it in a manner plainly inconsistent with the federal mandate. Consider, for instance, states' outright refusal to implement portions of the Patriot Act. ${ }^{61}$ But even these strong forms of agency are too quickly dismissed as disloyalty. Actions that involve direct challenges to federal mandates can be undertaken in the spirit of the loyal opposition. In these instances, minorities share the same basic goal as national policymakers (good education policy, sensible environmental regulation) even as they differ as to how to achieve it.

The literature on civil disobedience helps clarify the relationship between loyalty and resistance. Civil disobedience involves "the purposeful and public defiance of an established law or norm, undertaken with the intent of altering state policy." ${ }^{62}$ But civil disobedience is not purely oppositional, at least under most

61. Uniting and Strengthening America by Providing Appropriate Tools Required To Intercept and Obstruct Terrorism Act of 2001, Pub. L. No. 107-56, 115 Stat. 272 (2001) (codified as amended in scattered sections of the U.S.C.). For a full analysis, see Bulman-Pozen \& Gerken, supra note 38, at 1278-80.

62. David S. Meyer, Civil Disobedience, in EnCYClOPEDIA of DEMOCRATIC Thought 60, 60 (Paul Barry Clarke \& Joe Foweraker eds., 2001); see also JOHN RAWLS, A THEORY OF JUSTICE 363, 365 (1971) (defining civil disobedience within a "more or less just democratic state" as "a political act not only in the sense that it is addressed to the majority that holds political power, but also because it is an act guided and justified by political principles"). 
influential accounts. To the contrary, it is both an act of affiliation and of contestation. Martin Luther King described civil disobedience as "break[ing] an unjust law ... openly, lovingly." In the words of John Rawls, "It expresses disobedience to law within the limits of fidelity to law .... The law is broken, but fidelity to law is expressed by the public and nonviolent nature of the act, by the willingness to accept the legal consequences of one's conduct." ${ }^{64}$ For this reason, Rawls termed civil disobedience "that form of dissent" that stands "at the boundary of fidelity to law." evocative description of two civil-rights protests:

These are structured ceremonials of protest; they are not riots. The demonstrators were not . . . trying to bring government to a halt; rather they were expressing the concern of the young Negro about his situation. What was symbolized was a deep grievance, a break with the society. They prayed, they pledged allegiance to the flag, they sang "God Bless America," and-in [one instance]—-they even stopped for a red traffic light. ${ }^{66}$

Notice that the power of civil disobedience hinges on the dissenters' reaffirmation of their membership in the community. These acts of affiliation during the moment of dissent help protesters, to borrow a phrase Kalven uses elsewhere, "trap democracy in its own decencies." ${ }^{67}$

63. Martin Luther King, JR., Letter from Birmingham City Jail, in A Testament of Hope: The Essential Writings And SPeEches of MARTin Luther King, JR. 289, 294 (James M. Washington ed., 1986).

64. RAWLS, supra note 62, at 366; see also KING, supra note 63, at 294 ("[A]n individual who breaks a law that conscience tells him is unjust, and willingly accepts the penalty by staying in jail to arouse the conscience of the community over its injustice, is in reality expressing the very highest respect for law."). Indeed, even conventional dissent is not always purely oppositional. Dissenters often affirm their loyalty to the polity while declaring their disagreement. See generally, e.g., Robert N. Strassfeld, Lose in Vietnam, Bring the Boys Home, 82 N.C. L. REV. 1891 (2004) (documenting the strategy of Vietnam protesters to counter their opponents' equation of dissent and disloyalty). Steven Shiffrin even goes so far as to argue that dissent functions like a "cultural glue that binds [dissenters] to the political community." STEVEn H. SHIFFrin, Dissent, InJUSTICE, AND THE MEANINGS OF AMERICA 18 (1999).

65. RAWLS, supra note 62 , at 367.

66. Harry Kalven, Jr., The Concept of the Public Forum: Cox v. Louisiana, 1965 SuP. CT. REV. $1,6$.

67. Harry Kalven, JR., The Negro And the First Amendment 67 (1965). The lessons Kalven draws from civil-rights protests have apparently not been lost on the mayor of San Francisco, whose staff "made sure that when the mayor came out swinging against Bush's backing for a constitutional amendment banning same-sex marriage, he was standing in front of an American flag." Phillip Matier \& Andrew Ross, Newsom Hasn't Been Ad-Libbing, S.F. Chron., Feb. 29, 2004, at A19. 
Similarly, when minorities exercise agency-when they use their power as national agents to challenge the policy they are implementing-they look a good deal like civil disobedients. By virtue of their membership in the national governance structure, their challenges are understood as public and authoritative, not particular and private. The decisions minorities render are decisions of the polity, blessed as the decisions of the national government even as they depart from the national majority's preferences. And these decisions ensure that national policymaking reflects the heterogeneity of the national polity. If we think of civil disobedience as an activity designed to signal partial disagreement, agency offers an institutional channel for achieving the same end.

On this view, agency fits nicely with Walzer's conception of civil disobedience, which he argues involves "partial loyalty" rather than disloyalty. Walzer argues that civil disobedience stems from the problem of overlapping membership: "When obligations incurred in some small group come into conflict with obligations incurred in a larger, more inclusive group, generally the state. ${ }^{, 68}$ Someone engaged in civil disobedience, Walzer believes, has only "partial claims" against the state ${ }^{69}$ his "loyalties are divided," as "he is not in any simple sense a citizen" or a rebel but is instead partially both, precisely because "the processes through which men incur obligations are unavoidably pluralistic." ${ }^{, 0}$ Civil disobedients are thus "partial members[,] ... partial emigrants, partial aliens, partial rebels." Others have written in this vein. Hannah Arendt, for instance, termed civil disobedients "nothing but the latest form of voluntary association." " Similarly, Stephen Carter has argued that communities of faith are "separate sovereigns," dissenting communities embedded within the polity and yet not fully part of it.

Dissent that takes the form of agency can also be understood as an instantiation of the practice of pluralism, at least on Walzer's view. As with Walzer's account of civil disobedience, this form of dissent allows citizens to engage in partial rebellion and thus "builds loyalty

\footnotetext{
68. Michael Walzer, The Obligation to Disobey, 77 ETHICs 163, 167 (1967).

69. Id.

70. Id. at $169-70$.

71. Id. at 170.

72. Hannah ARendt, Civil Disobedience, in Crises of the RePublic 49, 96 (1972); see also id. at $75-76$.

73. Stephen L. Carter, The Dissent of the Governed: A Meditation on Law, RELIGION, AND LOYALTY 78 (1998); see also id. at 27-31.
} 
not only toward the state but also against it." ${ }^{, 74}$ Agency does not demand an external emigration to accompany what Walzer terms the "internal emigration" of a dissenter. ${ }^{75}$ Instead, minorities engaged in rebellious state or local policymaking are embedded insiders, not autonomous outsiders. They wield the power of the majority against itself. A minority can speak for the nation, just like any other citizen. To be sure, those engaged in dissent often affirm their membership in the polity. But here the polity, in effect, returns the favor by blessing - if only temporarily - the decision as its own.

Notions like partial loyalty and the loyal opposition might also help us sort agency from genuine disloyalty. The loyal opposition, for instance, understands the lesson of dualism. ${ }^{76}$ There are decisions, and then there are decisions. Although the loyal opposition can properly challenge decisions that have not yet been fully aired or vetted, we expect it to withdraw when the issue has been properly teed up and a national consensus has been reached. The loyal opposition, similarly, should take into account the costs of resistance. We expect it to act differently during times of emergency, for instance. Even during periods of normal politics, we expect the loyal opposition to exercise judgment; its job isn't to challenge everything merely for the sake of doing so. Similarly, just as we expect civil disobedients to accept the punishment for their law breaking, so too we might expect dissenters who exercise agency to accept the center's rebuke and step down when the center plays its trump card. Think, for instance, of the City of San Francisco, which stopped issuing same-sex marriage licenses the moment a court issued the appropriate order. ${ }^{77}$

\section{Is AGENCY WORTH CELEBRATING?}

Imagining agency as a path of influence would require us to celebrate rather than mourn the fact that Tocqueville's democracy fails to produce Weber's bureaucracy. In our mostly decentralized, partially politicized bureaucracy, minorities can contest state and federal policy from within rather than criticize it from without. Everyday citizens and political elites serve as nominal bureaucrats for

74. Michael WALZER, The Problem of Citizenship, in OBLIGATIONS: EsSAYS ON DisobEDIENCE, WAR, AND CITIZENSHIP 203, 220 (1970).

75. Walzer, supra note 68 , at 14.

76. See, e.g., 1 BRUCE ACKeRman, We the PeOPle: Foundations (1991).

77. Lockyer v. City of San Francisco, 95 P.3d 459, 467 (Cal. 2004); Dean E. Murphy, San Francisco Forced To Halt Gay Marriages, S.F. CHRON., Mar. 12, 2004, at A1. 
the federal government. The center's agents can exercise agency in their ongoing debate with the center.

One obvious reason for neglecting this topic is that it's simply not worth celebrating. Can anything be said in favor of Tocquevillian administration? Such a system plainly has costs, so familiar to all of us that we have a name for them (principal-agent problems). The question is whether these costs are so weighty that we should confine the "loyal opposition" to voice and exit and cut off opportunities for minorities to exercise agency (assuming it were possible to do so).

Here I don't want to make the witless claim. I won't argue that the principal-agent problem is never a problem or suggest that we should ignore the many conventional arguments that favor Weber over Tocqueville. But we know those arguments, and we don't have a full account of the alternative. My goal is to illuminate a set of arguments that are too often excluded from the cost-benefit calculus, not to do the math for you in advance. I will talk about some of those costs here, but only those that emerge when you think about minority influence in the terms I propose. I thus won't canvass the litany of grievances we conventionally associate with the principal-agent problem.

While much of my work has focused on the benefits generally associated with minority-dominated governance, here I want to focus on what makes agency distinctive as an avenue of minority influence-what differentiates it from voice and exit. The arguments pivot off the features I've already identified in explaining why minorities themselves might value agency: it gives them the opportunity to exercise control rather than voice and to do so inside the system rather than outside of it. That's all well and good for selfinterested minorities, of course, but what about the polity? Are there benefits to having a channel of influence that gives minorities control without forcing them to exit-a channel that grants both majority status and insider status in the decisionmaking process?

One crude way to break down the work in constitutional theory involving voice and exit is to notice that it is largely preoccupied with two projects. The first is dialogue-ensuring a healthy amount of debate and disagreement within our democracy. The second is integration-ensuring that our fractious polity remains a polity. Exit, voice, and agency all further these goals, but they do so in quite different ways. 


\section{A. Dialogue}

If we turn to one of the other main projects undergirding much of the work on constitutional theory-promoting healthy levels of dialogue and dissent—agency similarly offers some advantages over its institutional competitors.

Think about the rights side of the equation. We value the First Amendment because it offers dissenters voice (or, if you prefer, an exit option-that is, the exit option afforded by private speech or association). If we thought of agency as a third avenue for influence, we might imagine it serving as a competing or complementary channel for dissent. The same is true of federalism, which has long been thought to serve the same type of dialogic values as the First Amendment. Indeed, if we accept one of federalism's core insightsthat it is useful for governing institutions to serve as challengers to the national government ${ }^{78}$-we might think it is useful to introduce sources of contestation and dissent within the behemoth we call the Fourth Branch.

When states and localities are part of a federal administrative scheme, nominally bureaucratic roles are carried out by politicians, bureaucrats, and those who merge political savvy with technical expertise. This type of arrangement embeds would-be dissenters into the federal regime. It thus introduces the dynamics of federalism into

78. Consider the extant work, beginning with Ernest Young's argument analogizing states to the "shadow governments" found in European systems. Ernest A. Young, Welcome to the Dark Side: Liberals Rediscover Federalism in the Wake of the War on Terror, 69 BROOK. L. REV. 1277, 1286-87 (2004); see also Merritt, supra note 20, at 7. For a discussion of the role that states play in monitoring federal officials and training the loyal opposition, see Akhil Reed Amar, Some New World Lessons for the Old World, 58 U. CHI. L. REV. 483, 499-505 (1991); see also Baker \& Young, supra note 21, at 137-38. Andrzej Rapaczynski depicts local power as a "counterbalance" to federal lockup. Rapaczynski, supra note 17, at 386 . Vicki Jackson observes that the usefulness of "direct[ing] political activism and organizing" to states is precisely because their borders do not map on to divisive political identities. Vicki C. Jackson, Federalism and the Uses and Limits of Law: Printz and Principle?, 111 HARV. L. REV. 2180, 2221-23 (1998). Steven Calabresi asserts that "federalism sometimes can make minority groups feel secure while deemphasizing the lines of political and social cleavage." Calabresi, supra note 21, at 763-64. Judith Resnik discusses localism's role in promoting international rights and transnational cooperation. Judith Resnik, Law's Migration: American Exceptionalism, Silent Dialogues, and Federalism's Multiple Ports of Entry, 115 YALE. L.J. 1564 (2006). Daryl Levinson describes the role political parties play in diffusing power vertically. See generally Daryl J. Levinson, Empire-Building Government in Constitutional Law, 118 HARV. L. REV. 915, 938-44 (2005). 
the Fourth Branch, ensuring that federalism serves as a safeguard for a well-functioning administrative system. ${ }^{79}$

Agency also allows minorities to pursue their goals through administrative channels as well as political ones. Minorities thus have an additional set of leverage points in pursuing their agenda. Better yet, agency gives them the opportunity to offer a real-life instantiation of their views rather than an abstract argument in support of their claims. They need not merely claim that something can be done; they can show it can be done within the existing federal regime. Finally, as noted above, agency may be uniquely well suited for agenda setting. Precisely because it involves decisions made inside the system, it may be more likely to elicit a reaction from the center than will voice or exit.

One might respond that it is absolutely essential for challenges to the federal government to be protected by something-state sovereignty or a robust form of autonomy at the governance level; a constitutional right at the individual or group level. After all, if you are challenging the center, what good does it do to enact a policy only to have it reversed? Exit offers protection against reversal; agency does not.

It is certainly right to think that in some cases, agency won't amount to much as a channel of dissent. Some challenges will get squashed and squashed quickly. There is a risk that dialogue between the center and the periphery will be one-sided, with the center's only response a resounding "no." For dissenters, agenda-setting power is as volatile as it is valuable. Issues can get put on the national agenda too quickly. Minorities' decisions may thus produce backlash-not just political backlash, which can be elicited by other forms of dissent, but backlash that takes a legal and thus more permanent form as the center takes the steps necessary to reverse the periphery's decision.

There is a risk, however, that we overestimate these costs in thinking about dissent. That's because we ignore the trade-off that the notion of agency illuminates: protection from reversal also means one is outside of the system, and it might sometimes be just as useful to be making policy inside the system even if one risks reversal.

This is a bit abstract, so let me ground it with an example. Think about the difference between two same-sex marriage decisions that

79. See Bulman-Pozen \& Gerken, supra note 38, at 1286. 
occurred at roughly the same time: one in San Francisco, ${ }^{80}$ the other in Massachusetts. ${ }^{81}$ Massachusetts's decision fell squarely within the conventional federalism account-an exit option. Its decision was protected by sovereignty and thus shielded from reversal by the national majority. When San Francisco began licensing same-sex couples, in contrast, it could make no claim of sovereignty. Its decision could be reversed, and it was. ${ }^{82}$

Surely most people think that Massachusetts made the decision that really mattered for getting same-sex marriage on the national agenda. Sovereignty protected that decision from reversal, something that gave the state the power to continue with the experiment, to provide a real-life instantiation of its views that still stands today. No doubt this fact was important in shaping the ongoing debate. But notice that while Massachusetts's decision was initially condemned, it dropped out of the ongoing national discussion until recently. Had Massachusetts been fully separate from the United States-had it been France or the Netherlands-one wonders whether the decision would have elicited any response in this country.

San Francisco, in contrast, made the most of its status as an agent. Consistent with a sovereignty approach, Massachusetts's leadership tried to confine the effects of its decision to its own territory by limiting same-sex marriage licenses to state residents. ${ }^{83}$ San Francisco's leaders, however, leveraged the city's status as one actor embedded in a larger system by issuing marriage licenses to anyone willing to make the trip to California. This choice forced political actors in the states and the federal government-many of whom had previously ducked the issue - to take a stand on whether those marriages were valid. San Francisco, in other words, took advantage of its status as one part of a larger policymaking regime to wield one of the most powerful tools that a dissenter can have-the power to set the agenda.

To get some sense of why agenda setting matters so much to dissenters, think about the First Amendment. Our iconic image is of a person standing on a soapbox. Now think about what you do when

80. Lockyer, 95 P.3d 459.

81. Goodridge v. Dep’t of Pub. Health, 798 N.E.2d 941 (Mass. 2003).

82. See supra note 77 and accompanying text.

83. Pam Belluck, Romney Won't Let Gay Outsiders Wed in Massachusetts, N.Y. TIMES, Apr. 25, 2004, at N1. The state ultimately abandoned this policy and ended up marrying samesex couples from out of state. Katie Zezima, Massachusetts: Same-Sex Couples from Other States May now Marry, N.Y. TiMES, Aug. 1, 2008, at A13. 
you see someone on that soapbox. You walk on by. That might seem like a trivial point. But often the majority's best strategy in dealing with dissent will be radio silence, ignoring the challenge rather than engaging with it. That option simply became unavailable when San Francisco took advantage of its status as an agent in a larger administrative structure and began marrying people from across the country.

Because San Francisco was a servant rather than a sovereign, an agent rather than a principal, it could be reversed . . . and reversed and reversed and reversed. But, here again, one wonders whether San Francisco had more of an effect on this debate precisely because it repeatedly forced the majority to engage. Attempts to shut down the city's efforts prompted two high-profile, state-court battles, backlash in the form of an initiative, and backlash to the backlash initiative. The city is now engaged in a third, high-profile court case that is before the Supreme Court at the time of this writing. ${ }^{84}$ And note that Massachusetts has recently reemerged in this debate only because a judge held that the federal government could not deny marriage benefits to same-sex couples married within the state, ${ }^{85}$ thus leveraging Massachusetts's status as an integrated part of the federal regime in order to force the national government to engage. Should this effort be short-circuited by an adverse ruling, then it is hard to tell whether, in the end, Massachusetts will look like the solitary dissenter on the soap box, precisely because it stands outside the system and cannot be reversed, whereas San Francisco, playing the servant's role, will ultimately do more to push the same-sex marriage debate forward in the long run.

Note the connection between these arguments and those I made earlier about agency. Here again, we see the same relationship between exit and voice, outsiders and insiders. It is precisely when states and localities are integrated into a national scheme-rather than standing separate and apart from it-that they have the power to set the agenda, to force a reluctant national elite to engage.

Note also the connections here between agency and civil disobedience. Each forces the majority to act-either to overrule the outlier decision (agency) or to prosecute the dissenters (civil

84. Perry v. Brown, 671 F.3d 1052 (9th Cir), cert. granted sub nom. Hollingsworth v. Perry, 133 S. Ct. 786 (Dec. 7, 2012) (No. 12-144). In the interest of full disclosure, I should note that I supervise a program that has allowed Yale Law students to work on this case.

85. Massachusetts v. U.S. Dep't of Health \& Human Servs., 682 F.3d 1, 5 (1st Cir. 2012). 
disobedience). Both thus, to borrow a phrase from Martin Luther King, help "create ... a crisis and establish such creative tension that a community ... is forced to confront the issue." ${ }^{, 86}$ Like Alexander M. Bickel's account of civil disobedience, agency is "an exercise of power in the sense in which Burke defined it": an "attempt to coerce the legal order." ${ }^{\prime 87}$ Agency, in short, offers a key advantage precisely because it cedes to would-be dissenters control over decisions without forcing them to exit. In contrast to exit and voice, it helps ensure that dialogue between the periphery and center-at the heart of both First Amendment and federalism theory-actually happens.

If we are thinking about costs and benefits, of course, there are many instances when the polity might sensibly prefer not to have a decision forced upon it. Sometimes the issue has been settled, and properly so. We might well think in these situations that the only appropriate channels for dissent are voice and exit: speak up or get out. And a national government simply can't function if it has to quash local rebellion whenever it makes a decision.

Agency, though, also offers something that the polity might find useful when compared to voice and exit. The model presumes that the center can and should quash local rebellion when it sees fit. Exit-a conventional federalism model or a robust right to associate-shields policies that depart from a treasured national consensus. Agency, in contrast, makes space for the center to reverse the periphery when the latter pushes too hard. All the national majority needs to do is spend the political capital necessary to do so. In some situations, then, agency offers the polity a good deal more flexibility in dealing with would-be dissenters than exit provides.

Another feature that distinguishes agency from voice or exit is that it extends the time frame for dissent. ${ }^{88}$ Those outside the national policymaking apparatus often have only a few realistic opportunities to influence a policy_for example, just before Congress passes a law or an agency issues a regulation. In these situations, the arguments aired by dissenters will often be cast in abstract terms, a great deal of pressure will be placed on the politicking that occurs ex ante, and the

86. KING, supra note 63, at 291; see also RAWLS, supra note 62, at 366 ("By engaging in civil disobedience a minority forces the majority to consider whether it wishes to have its actions construed in this way, or whether, in view of the common sense of justice, it wishes to acknowledge the legitimate claims of the minority.").

87. AleXander M. Bickel, The Morality of Consent 99 (1975).

88. Bulman-Pozen \& Gerken, supra note 38, at 1292-93. 
key players in the debate will be interest groups, lobbyists, and politicians.

If would-be dissenters enjoy opportunities to exercise agency, the ongoing conversation between the center and the periphery will look quite different, something that can be characterized as a feature or a bug. On the positive side, the debate is likely to be informed by facts on the ground. Any debate that takes place ex post will, of course, offer a better sense of what a policy looks like in practice. And dissenters who serve as agents of the center are likely to have a closer view of the facts on the ground and access to a wider range of facts. Giving would-be dissenters two bites at the policymaking apple might lower the stakes of the debate, as dissenters will know that they will have a chance to soften the edges of a policy they oppose. The conversation between the center and the periphery won't be a one-off battle, but is likely to be iterative. Finally, ex post policymaking debates are likely to involve a different set of actors than ex ante ones. These debates are more likely to include experts, or at least those with experience and a shared sense of mission.

There are, of course, costs to extending the time frame for debate. It allows dissenters to pursue a "death by a thousand cuts" strategy in challenging national policy. It gives them an opportunity to resist a policy sub rosa, without having to make their case on a public stage. Iterative processes aren't always superior ones. Although we typically imagine an iterative process to be a dialogic one, an iterative process can also convert a one-off battle into an ongoing war. And while these debates include a different set of decisionmakers, conversations within the informal, administrative realm may be less transparent-and thus less likely to include representatives of all stakeholding groups-than debates that take place during legislating or rulemaking.

Dissent that takes place in the interstices of federal policy will also look quite different from dissent that takes the form of voice. Agency cedes to dissenters genuine power-the power to make national policy rather than merely complain about it. But it also requires that dissenters pour their complaints into a fairly narrow policymaking space. Voice, in contrast, gives dissenters a chance to "get [their] genius expressed whole and entire." ${ }^{89}$ When they speak, they can offer a fully articulated argument in favor of their position.

89. Virginia WoOlF, A RoOM OF ONE's OWn 75 (reprt. 1991) (1929). With apologies to Virginia Woolf. 
When they vote, they can express their disagreement across a far wider range of issues than they will encounter as agents within one policy domain or another. ${ }^{90}$

\section{B. Integration}

Think, for instance, about how "control without exit" fits with the extant work on dissent and the project of integration. This is a project I've taken up elsewhere,$^{91}$ so here I'll offer just a thumbnail sketch. Many argue that the purpose of the First Amendment is to integrate political outliers into the polity. ${ }^{92}$ But, interestingly enough, the strategies we have for doing so at least partially reify their status as minorities and outsiders. The rights afforded to dissenters push them outside of the project of governance. They can speak their mind, but only when they speak for themselves. They can speak truth to power, but not with it.

Similarly, while federalism involves minorities in the project of governance, it does so only by allowing them to migrate to separate polities rather than to help govern on behalf of the polity. When dissenters are engaged in the project of governance inside the national system, they are condemned to the status of perpetual losers.

It's not hard to imagine that political minorities might value the chance to serve as policymaking insiders rather than autonomous outsiders. They might value the chance to stand in the shoes of the majority, to develop a different set of participatory skills, to enjoy the efficacy associated with agency. Agency, then, might exercise a centripetal force, pulling outliers into the national polity.

Agency, of course, involves costs as well. Even if we discount the costs conventionally associated with bureaucratic dissensus, we might worry that agency can undermine the project of integration. While it's all well and good to create opportunities for political minorities to enjoy decisionmaking control, agency carries with it the risk of reversal. And it might be quite debilitating for minorities to see their decisions subject to immediate reversal-all that work for nothing. Indeed, reversal might cause minorities to be less invested in the process going forward.

90. Thanks to Yair Listokin for pushing me on this point.

91. See generally, e.g., CARTER, supra note 73, at 97-98; Gerken, supra note 26; Heather K. Gerken, Second-Order Diversity, 118 HARV. L. REV. 1099 (2005).

92. See, e.g., SHIFFrIN, supra note 64, at 18; Thomas I. Emerson, Toward a General Theory of the First Amendment, 72 YALE L.J. 877, 885 (1963). 
Or it might not. Political setbacks can pull people still deeper into the process. Consider, for instance, the path the Christian Right took into politics. Early defeats galvanized more organizing. Decisions on abortion led to increasingly creative legislation and newly minted arguments designed to counter critics. Decisions on school prayer led members of the Christian Right to take over school boards.

These interactions didn't just pull political outliers into national politics; it caused them to moderate their arguments as they poured their views into a small policymaking space and carried on their continuing conversation with the center. Pro-life arguments, for instance, now routinely include appeals to the needs of women. ${ }^{93}$ Supporters of religion in schools have gone from teaching the Creation to teaching the controversy.

****

When one lays voice, exit, and agency side by side, it becomes clear that agency offers a competing and complementary channel for minority influence. Voice and exit have long been thought to play important roles in holding a fractious national polity together. Agency can play the same role because it offers minorities control without exit, the status of the majority paired with the status of the insider.

\section{CONCLUSION}

Let me conclude by returning to the puzzle with which I began. We are all aware of the principal-agent problem. We are all aware of the power that agents wield in a highly decentralized, partially politicized system like our own. But these institutional arrangements - which will only become more important as local, state, and national regulatory structures become more integratedhave long been neglected by constitutional theorists. Constitutional theory has devoted a great deal of energy to the question of what a democracy owes its minorities. We have fully theorized accounts of voice and exit on both the structural and the rights side of the equation. But we have spent relatively little time on the possibility

93. See Reva B. Siegel, The Right's Reasons: Constitutional Conflict and the Spread of Woman-Protective Antiabortion Argument, 57 DUKE L.J. 1641, 1688 (2008). 
that minorities might make policy rather than complain about it, that they might wield power within the system rather than outside of it, that they might serve as connected critics rather than autonomous outsiders. We have missed the possibility that agency provides a third avenue of influence for minorities in a majoritarian system.

None of this is to suggest that agency is without cost. But neither is voice nor exit (that is one of Hirschman's key points). The fact that federalism involves costs doesn't prevent us from celebrating it. The same should hold true of uncooperative federalism. The fact that dissent involves costs doesn't prevent us from revering it; the same should hold true of dissenting by deciding. Even if you think that agency is, on balance, harmful to our constitutional scheme, at the very least it's useful to recognize its existence. What is useful about Hirschman's framework is that it allows us to compare and contrast exit and voice, two competing and complementary channels of minority influence. Adding a third category to Hirschman's typology can only enrich our understanding of how our democracy functions. 